*alls View/Frint Document Cover Sheet tose

This document was retrieved from the Boeing ISEARCH System.

Accession \#: D196069886

Document \#: SD-WM-TP-353

Title/Desc:

TANK 241B106 TANK CHARACTERIZATION PLAN 


\begin{tabular}{|c|c|c|c|c|c|c|}
\hline \multirow{3}{*}{\multicolumn{2}{|c|}{$\begin{array}{l}\text { 2. ECK Category } \\
\text { (mark one) } \\
\text { Supplemental } \\
\text { Oirect Revision } \\
\text { Change ECN } \\
\text { Tenporary } \\
\text { Standby } \\
\text { Supersedure } \\
\text { Cancel/Noid }\end{array}$}} & \multicolumn{2}{|c|}{$\begin{array}{l}\text { 3. Originator's Name, Organization, MSIN, } \\
\text { and Telephone No. } \\
\text { C. S. HOMI, 75320, R2-12, 373- } \\
1097\end{array}$} & \multicolumn{2}{|c|}{$\begin{array}{l}\text { 3a. Usa Required? } \\
\text { [] Yes }[X] \text { No }\end{array}$} & $\begin{array}{l}\text { 4. Date } \\
10 / 04 / 95\end{array}$ \\
\hline & & \multicolumn{2}{|c|}{$\begin{array}{l}\text { 5. Project Title/Ho./Work order No. } \\
\text { TANK 241-B-106 TANK } \\
\text { CHARACTERIZATION PLAN }\end{array}$} & \multicolumn{2}{|c|}{$\begin{array}{l}\text { 6. Bldg./Sys./Fac. No. } \\
\text { B-106 }\end{array}$} & $\begin{array}{l}\text { 7. Approval Designator } \\
\text { N/A }\end{array}$ \\
\hline & & \multicolumn{2}{|c|}{$\begin{array}{l}\text { 8. Document Numbers Changed by this ECN } \\
\text { (includes sheet no. and rev.) } \\
\text { WHC-SD-WM-TP-353 REV } \backslash 0\end{array}$} & \multicolumn{2}{|c|}{$\begin{array}{l}\text { 9. Related ECN No(s). } \\
\text { N/A }\end{array}$} & $\begin{array}{l}\text { 10. Related PO No. } \\
\qquad \text { N/A }\end{array}$ \\
\hline \multicolumn{2}{|c|}{$\begin{array}{l}\text { 11a. Modification Work } \\
\text { [] Yes (fill out Blk. } \\
11 \mathrm{~b}) \\
{[X] \text { No (NA Blks. 11b, }} \\
\text { (1c, idd) }\end{array}$} & $\begin{array}{l}\text { 11b. Work Package } \\
\text { No. } \\
\text { N/A }\end{array}$ & \multicolumn{2}{|c|}{$\begin{array}{l}\text { 11̣c. Modification Hork Complete } \\
\text { N/A } \\
\text { Cog. Engineer Signature \& Date }\end{array}$} & \multicolumn{2}{|c|}{$\begin{array}{l}\text { 11d. Restored to Original Condi- } \\
\text { tion (Temp. or Standby ECN only) } \\
\text { N/A }\end{array}$} \\
\hline \multicolumn{7}{|c|}{$\begin{array}{l}\text { 12. Description of Change } \\
\text { Complete revision. }\end{array}$} \\
\hline
\end{tabular}

12. Description of Change

Complete revision.

13a. Justification (mark one)

Criteria Change $[X]$ Design improvenent As-found [] Facilitate Const [] Const. Error/Omission

[] Facility Deactivation Design Error/Omission

13b. Justification Details

Format change. 


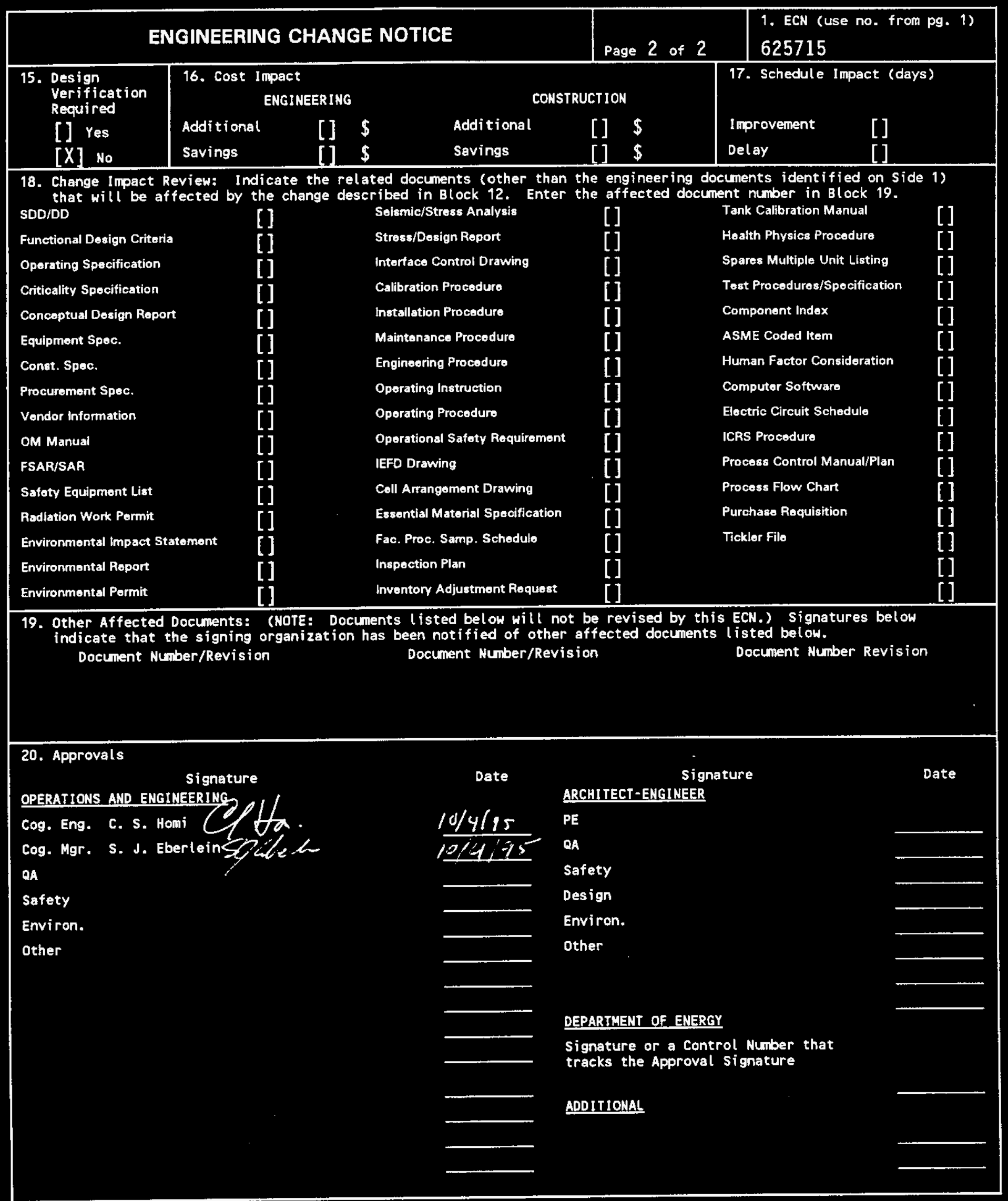




\section{RELEASE AUTHORIZATION}

Document Number: WHC-SD-WM-TP-353, REV 1

Document Title: Tank 241-B-106 Tank Characterization Plan

Release Date: $\quad 10 / 4 / 95$

This document was reviewed following the procedures described in WHC-CM-3-4 and is:

APPROVED FOR PUBLIC RELEASE

WHC Information Release Administration Specialist:
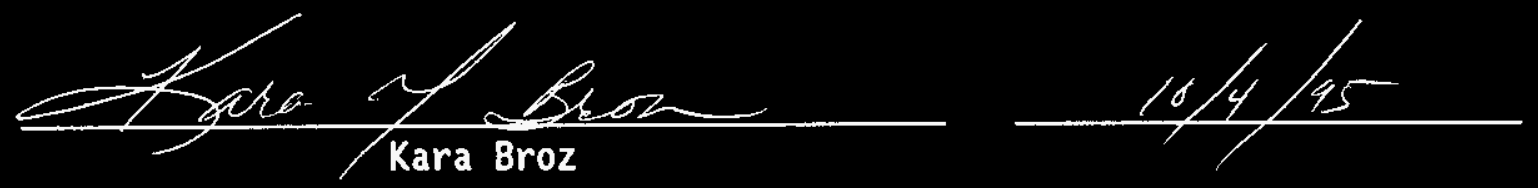

TRADEMARK DISCLAIMER. Reference herein to any specific commercial product, process, or service by trade name, trademark, manufacturer, or otherwise, does not necessarily constitute or imply its endorsement, recommendation, or favoring by the United States Government or any agency thereof or its contractors or subcontractors.

This report has been reproduced from the best available copy. Available in paper copy. Printed in the United States of America. To obtain copies of this report, contact:

Westinghouse Hanford Company - Document Control Services

P.0. Box 1970, Mailstop H6-08, Richland, WA 99352

Telephone: (509) 372-2420; Fax: (509) 376-4989 


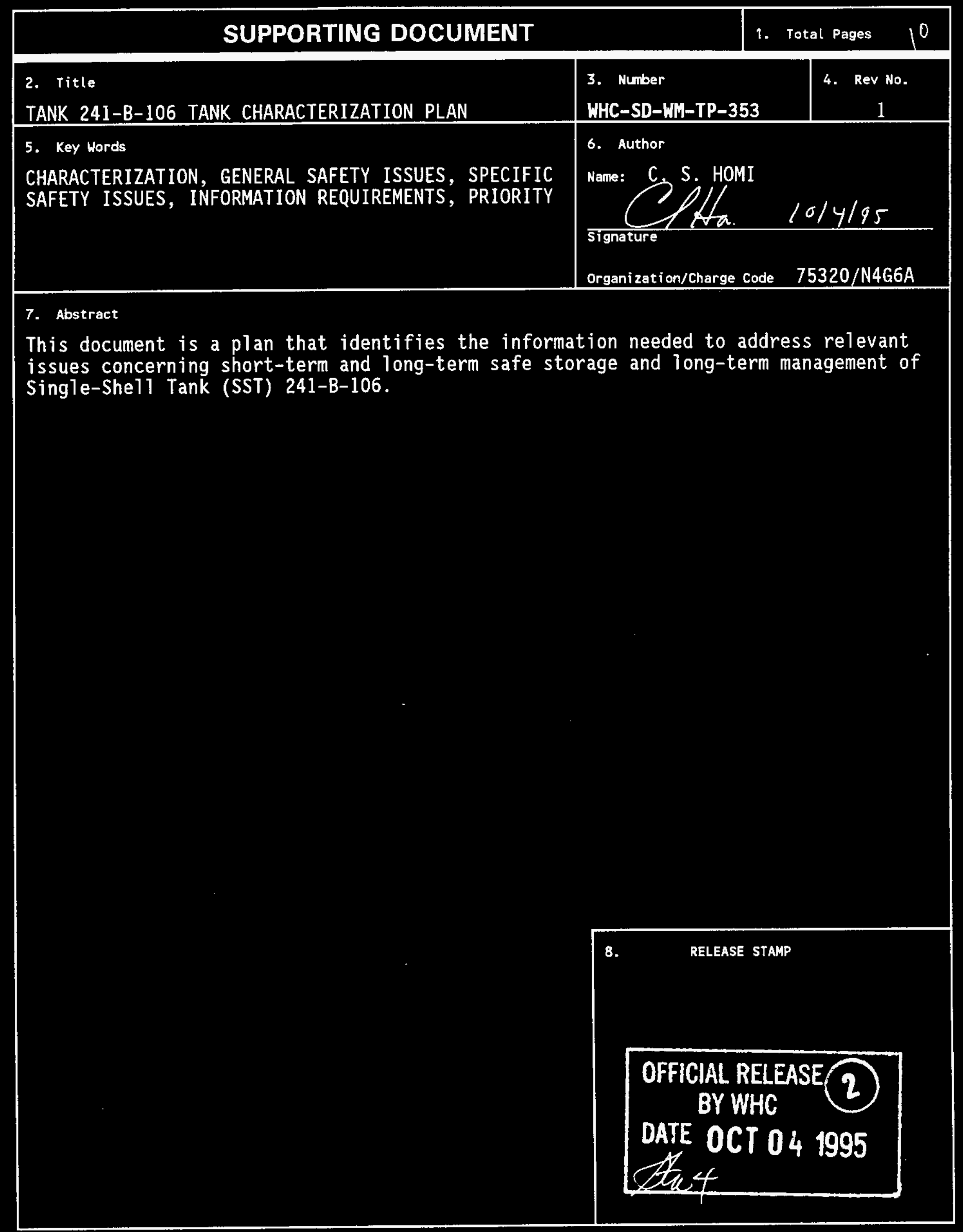


RECORD OF REVISION

(1) Document Number

WHC-SD-WM-TP-353

Page 1

(2) Title

TANK 241-B-106 TANK CHARACTERIZATION PLAN

CHAWEE CONTROL RECORD

\begin{tabular}{|c|c|c|c|}
\hline \multirow{2}{*}{ (3) Revision } & \multirow{2}{*}{ (4) Description of Change - Replace, Add, and Delete Pages } & \multicolumn{2}{|c|}{ Authorized for Release } \\
\hline & & (5) Cog. Engr. & (6) Cog. Mgr. \\
\hline 0 & $\begin{array}{l}\text { (7) WHC-SD-WM-TP-353 REV. 0, EDT 610420, } \\
\text { June 15, } 1995\end{array}$ & & \\
\hline os 1 & Complete revision to new format, ECN 625715 & CAta. & 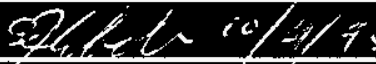 \\
\hline & & & t \\
\hline & & & \\
\hline & & & \\
\hline & & & \\
\hline & & & \\
\hline & & & \\
\hline & & & \\
\hline & & & \\
\hline & & & \\
\hline & & & \\
\hline & & & \\
\hline & & & \\
\hline & & & \\
\hline & & & \\
\hline & & & \\
\hline & & & \\
\hline & & & \\
\hline & & & \\
\hline & & & \\
\hline & & & \\
\hline & & & \\
\hline & & & \\
\hline & & & \\
\hline & & & \\
\hline & & & \\
\hline & & & \\
\hline & 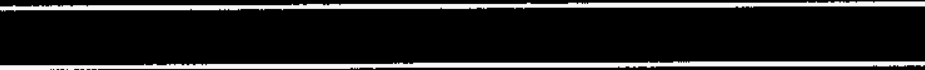 & & \\
\hline
\end{tabular}




\title{
Tank 241-B-106 Tank Characterization Plan
}

\author{
C. S. Homi \\ Westinghouse Hanford Company
}

Date Published

October 1995

Prepared for the U.S. Department of Energy Office of Environmental Restoration and Waste Management

Westinghouse
(2.0 Box 1970
Hanford Company Richland. Weshington

Management and Operations Contractor for the

U.S. Deparment of Energy under Contract DE-AC06-87FL 10930 
WHC-SD-WM-TP-353, REV 1

\section{TABLE OF CONTENTS}

1.0 INTRODUCTION

2.0 PROGRAM ELEMENTS REqUIRING INFORMATION FOR 241-B-106 . . . . . . . . . . . 2

2.1 GENERAL SAFETY ISSUES . . . . . . . . . . . . . . . . . . . . 2

2.2 SPECIFIC SAFETY ISSUES . . . . . . . . . . . . . . . . . . . 2

2.2.1 Ferrocyanide . . . . . . . . . . . . . . . . 2

2.2.2 Organic ......................... 2

2.2.3 High Heat ......................... 2

2.2.4 Flammable Gas ...................... 2

2.2 .5 Vapor .......................... 2

2.2.6 Criticality . . . . . . . . . . . . . . . . . . . 3

2.2.7 Screening Approach Evaluation ............... . 3

2.3 CONTINUTNG OPERATIONS . . . . . . . . . . . . . . . . . . . . . 3

2.2.1 Compatibility/Stabilization ............... 3

2.2.2 Evaporator ........................ 3

2.4 DOUBLE-SHELL TANK WASTE ANALYSIS PLAN . . . . . . . . . . . . . . . 3

2.5 DISPOSAL . . . . . . . . . . . . . . . . . . . . . 3

2.5.1 Retrieval ........................ 3

2.5.2 Pretreatment/Vitrification.............. 3

2.6 HISTORICAL MODEL EVALUATION . . . . . . . . . . . . . . . . . 3

3.0 HON INFORMATION WILL BE OBTATNED . . . . . . . . . . . . . . . . . . . . . 4

4.0 PRIORITY OF INFORMATION REQUIREMENTS . . . . . . . . . . . . . . . . . . 4

5.0 WHEN INFORMATION IS NEEDED . . . . . . . . . . . . . . . . . . . . 4

6.0 REFERENCES ................................. 5

\section{LIST OF TABLES}

Table 4-1: Integrated DQO Requirements . . . . . . . . . . . . . . . 4 
WHC-SD-WH-TP-353, REV 1

\section{LIST OF ABBREVIATIONS}

$\begin{array}{ll}\text { B-106 } & \text { Tank 241-B-106 } \\ \text { DQO } & \text { Data Quality Objective } \\ \text { HTCE } & \text { Historical Tank Content Est imate } \\ \text { DSSF } & \text { Double She11 Slurry Feed } \\ \text { NCPLX } & \text { Non-complexed } \\ \text { SST } & \text { Single-She11 Tank } \\ \text { TCP } & \text { Tank Characterization P1an } \\ \text { TOC } & \text { Total Organic Carbon } \\ \text { USQ } & \text { Unreviewed Safety Question } \\ \text { WHC } & \text { Westinghouse Hanford Company }\end{array}$




\subsection{INTRODUCTION}

This Tank Characterization Plan (TCP) identifies the information needed to address relevant issues concerning short-term and long-term safe storage and long-term management of Single-She11 Tank 241-B-106 (B-106). It should be understood that the various needs and issues surrounding tank B-106 are evolving as new information about the tank is uncovered. As a result of this progression, this Tank Characterization Plan addresses only the issues that, to this date, have been identified. It is expected that deviations from this plan may occur as additional issues or needs arise which impact the management of SST B-106. As necessary, this Tank Characterization Plan will be revised to reflect those changes or deviations.

Tank B-106 was constructed between 1943 and 1944 and was put into service in August 1947. Initially tank B-106 received second cycle waste from the third quarter of 1947 until May 1948. The tank received waste via cascade overflow from B-105, from the third quarter of 1947 until the second quarter of 1950 . Waste was transferred from B-104 to a crib during December 1948, first quarter of 1949 and the first and second quarters of 1950. From the second quarter of 1952 unti1 the first quarter of 1953, the tank contained first cycle waste. B-106 contained evaporator bottoms waste in the second quarter of 1953. From the third quarter of 1952 to the third quarter of 1954, B-106 was an evaporator feed tank. From the third quarter of 1953 to the third quarter of 1959, B-106 contained U Plant waste. Scavenged feed was pumped from B-106 to C-101 during the fourth quarter of 1957. B-106 received wastewater from the second quarter of 1959 until the second quarter of 1971. The tank contained U Plant waste and Hanford laboratory operations waste from the fourth quarter of 1959 until to the third quarter of 1968. From the fourth quarter of 1968 to the second quarter of 1969, B-106 contained waste from U Plant and Battelle Pacific Northwest Laboratory. From the third quarter of 1969 to the first quarter of 1971, B-106 contained only Battelle Pacific Northwest Laboratory waste. From the second quarter of 1971 until the second quarter of 1974, the tank contained Battelle Pacific Northwest 1aboratory waste and 224-U waste. Presently, the tank waste is classified as non-complexed. This tank currently contains waste with a total waste volume of $442.9 \mathrm{~kL}$ (117 kgal), which is equivalent to 96.5 centimeters ( 38.0 inches) of waste as measured from the baseline of the tank. The waste is comprised of $439.1 \mathrm{~kL}(116 \mathrm{kgal})$ of saltcake and $3.8 \mathrm{~kL}$ (1 $\mathrm{kgal}$ ) of supernatant with pumpable liquid remaining (Brevick 1994a).

The tank is categorized as sound and was declared inactive 1978. Tank B-106 is passively ventilated and interim stabilized in March 1985 with intrusion prevention completed. The last photo was taken on February 28, 1983. The 1985 montage indicates a thin liquid surface over reddish-brown saltcake (Brevick 1994b). Supernatant was pumped from B-106 after this montage was taken; therefore, this montage description does not represent current tank contents. The last solids volume update was obtained on March 31, 1985 (Hanlon 1995).

An analysis was conducted on a B-106 sample in December 1975. The sample was yellow and contained no solids. When the sample was cooled to $5^{\circ} \mathrm{C}, 2 \%$ of the sample precipitated to solids.

This tank is not on any Watch list. Near-term sampling and analysis activities are focused on either verification of the non-watchlist tank status, identification of any new safety issues or changing the non-Watch List status. Should any safety issues be identified additional analys is will occur consistent with the identified issue. 
In addition to the resolution of the safety. issues, it is intended that all tank waste will be subject to pretreatment and retrieval to prepare for final storage or disposal. Presently, these long-range plans have yet to be fully identified and are, therefore, not included in this document.

\subsection{PROGRAM ELEMENTS REQUIRING INFORMATION FOR TANK 241-B-106}

This section identifies the various program elements, and identifies which of these programs require characterization data from tank B-106.

\subsection{GENERAL SAFETY ISSUES}

The Tank Safety Screening Data Quality Objective (Babad 1995) describes the sampling and analytical requirements that are used to screen waste tanks for unidentified safety issues. The primary analytical requirements for the safety screening of a tank are energetics, total alpha activity, moisture content, and flammable gas concentration.

\subsection{SPECIFIC SAFETY ISSUES}

\subsubsection{Ferrocyanide}

This tank is not on the Ferrocyanide Watch List and; therefore, no information needs are currently identified for this program element.

\subsubsection{Organic}

Tank B-106 is not on the Organics Watch List and; therefore, no information needs are currently identified for this program element.

\subsubsection{High Heat}

This tank is not on the High Heat Watch List and; therefore, no information needs are currently identified for this program element.

\subsubsection{Flanmable Gas}

This tank is not on the Flammable Gas Watch List and; therefore, no information needs are currently identified for this program element.

\subsubsection{Vapor}

The tanks currently scheduled to be vapor sampled may be classified into four categories: (1) those tanks which are to be rotary mode core sampled (as a consequence of the rotary sampling system); (2) tanks on the Organic or Ferrocyanide Watch Lists; (3) tanks in C farm; and (4) tank BX-104, due to vapor exposure. Since tank B-106 is not categorized in one of the above four groups, vapor sampling is not required for this tank. 


\subsubsection{Criticality}

No information separate from that for the general safety issue of tank B-106 are currently identified for this program element. However, if the general safety screening of tank B-106 identifies a potential criticality concern, analyses for fissile materials and neutron absorbers and poisons will be performed as identified in the safety screening data quality objective.

\subsubsection{Screening Approach Evaluation}

The safety screening approach is currently under review. Information is required from key tanks to determine if a revised approach to screening may be adopted, as proposed in Meacham, 1995.

\subsection{CONTINUING OPERATIONS}

\subsubsection{Compatibility/Stabilization}

No information needs are currently identified for this program element.

\subsubsection{Evaporator}

No information needs are currently identified for this program element.

\subsection{DOUBLE-SHELL TANK WASTE ANALYSIS PLAN}

No information needs are currently identified for this program element, although work to identify these needs is in progress and expected to be completed in fiscal year 1995.

\subsection{DISPOSAL}

\subsubsection{Retrieval}

Current retrieval needs (Bloom 1995) do not call for test samples to be taken from tank B-106.

\subsubsection{Pretreatment/Vitrification}

Tank B-106 has been identified as a bounding tank for pretreatment/disposal process development (Kupfer 1995).

\subsection{HISTORICAL MODEL EVALUATION}

Bounding tanks and data requirements for historical model evaluations are found in DQO Historical Model Evaluation Data Requirements (Simpson 1995). Tank B-106 has been identified as an alternative bounding tank for the B saltcake waste type, but will not be assessed against the historical $0 Q 0$ unless directed by the program. 


\subsection{HOW INFORMATION WILL BE OBTATNED}

The safety screening DQO requires that a vertical profile of the tank waste be obtained from at least two widely spaced risers. This vertical profile may be obtained using core, auger (for shallow tanks), or grab samples. Only a push mode sampling event is scheduled and required. No other sampling is scheduled through fiscal year 1997 (Stanton 1995). The push mode sampling type has been chosen over other sampling modes due to both the depth of the tank (making auger sampling inadequate) and the fact that the surface of tank B-106 is comprised of supernatant and sludge.

The best current estimate of the water content in tank B-106 solids, as determined from the process records, is $56.3 \%$; based on the HTCE (Brevick 1994a). Estimated (Toth et al 1995) water content in tank B-106 sludge is $49.5 \%$ (generated from a mode 1 based on sample data from similar tanks). If the variance of water in tanks already sampled and a statistical power curve is used then a minimum of two cores are needed to demonstrate a water content above $17 \%$ at $95 \%$ confidence. Should the measured mean be lower than anticipated or the measured variance higher, additional samples may be required. The TOC contained within the sludge is estimated (Toth et al 1995) to be $0.1 \%$ (wet basis), which is significantly lower than the level of concern. Two core samples will be requested for this tank and this should meet the requirements for the above parameters.

Presently there is no information on the availability of tank B-106 risers, however two Push Mode samples with 2 segments each were collected in July 1995.

\subsection{PRIORITY OF INFORMATION REQUIREMENTS}

Vapor sampling is not required for this tank. Push mode sampling was completed in July 1995 (Stanton 1995).

Table 4-1: Integrated DQO Requirements

\begin{tabular}{|l|l|l|l|}
\hline $\begin{array}{l}\text { Sampling Event } \\
\text { Eppl icable DQ0 }\end{array}$ & Sampling Requirements & Analytical Requirements \\
\hline $\begin{array}{l}\text { Push Mode } \\
\text { Sampling }\end{array}$ & $\begin{array}{l}\text {-Safety Screening DQO } \\
\text {-Pretreatment DQO }\end{array}$ & $\begin{array}{l}\text { Core samples from 2 } \\
\text { risers separated } \\
\text { radially to the maximum } \\
\text { extent possible }\end{array}$ & $\begin{array}{l}\text { Energet ics, Moisture, } \\
\text { Total Alpha, Total } \\
\text { Organic Carbon, SpG }\end{array}$ \\
\hline
\end{tabular}

\subsection{WHEN INFORHATION IS NEEDED}

Data are required for Tank B-106 during FY 1996 for safety screening and to prepare a Tank Characterization Report. 


\subsection{REFERENCES}

Babad, H, K. S. Redus, and J. W. Hunt, 1995, Tank Safety Screening Data Quality Objective, WHC-SD-WM-SP-004, Rev 1, Westinghouse Hanford Company, Richland, Washington.

Bloom, G. R., and Q. H. Nguyen, 1995, Characterization Data Needs for Development, Design, and Operation of Retrieval Equipment Developed Through the Data Quality Objective Process, WHC-SD-WM-DQ0-008, Rev. 0, Westinghouse Hanford Company, Richland, Washington.

Brevick, C. H., 1994a, Historical Tank Content Estimate for the Northeast Quadrant of the Hanford 200 East Areas, WHC-SD-WM-ER-349, Rev. OA, ICF Kaiser Hanford Company, Richland, Washington.

Brevick, C. H., 1994b, Supporting Document for the Historical Tank Content Estimate for BX Tank Farm, WHC-SD-WM-ER-311, Rev. 0, ICF Kaiser Hanford Company, Richland, Washington.

Brown, T. M., S. J. Eberlein, D. A. Dodd, T. J. Kunthara, B. C. Simpson, and N. W. Kirch, Tank Waste Characterization Plan and Basis, 1995, WHC-SD-WM-TA-164, Rev 0, Westinghouse Hanford Company, Richland, Washington.

Hanlon, B.M., 1995, Waste Tank Summary for Month Ending May, 1995, WHC-EP-0182-82, Westinghouse Hanford Company, Richland, Washington.

Homi, C. S., and S. J. Eberlein, 1995, Fiscal Year 1996 Tank Waste Remediation System Tank Waste Analysis Plan, WHC-SD-WM-PLN-101, Rev 0, Westinghouse Hanford Company, Richland, Washington

Kupfer, M. J., W. W. Schultz, and J. T. Slankas, 1995, Strategy for Sampling Hanford Site Tank Wastes for Development of Disposal Technology, WHC-SD-WM-TA-154, Rev. 1, Westinghouse Hanford Company, Richland, Washington.

Meacham, J. E., R. J. Cash, B. A. Pulsipher, and G. Chen, 1995, Data Requirements for the Ferrocyanide Safety Issue Developed through the Data Quality objectives Process, WHC-SD-WM-DQ0-007, Rev. 1, Westinghouse Hanford Company, Richland, Washington.

Price, D. N., 1994, Rotary Core Vapor Sampling Data Quality Objective, WHC-SD-WM-SP-003, Rev. 0, Westinghouse Hanford Company, Richland, Washington.

Simpson, B. C., and D. J. McCain, 1995, Historical Model Evaluation Data Requirements, WHC-SD-WM-DQ0-018, Rev. 0, Westinghouse Hanford Company, Richland, Washington.

Stanton, G. A., 1995, Baseline Sampling Schedule, Revision 4.4, (internal memo 74320-95-04, to distribution, March 24), Westinghouse Hanford Company, Richland, Washington.

Toth, J. J., P. G. Heasler, M. E. Lerchen, J. G. Hill, and P. D. Whitney, 1995, Analysis of Organic Carbon and Moisture in Hanford Single-Shel1 Tank Waste, PNL10360, Pacific Northwest Laboratory, Richland, Washington. 